\title{
Does spatial scale affect the pattern of mangrove change under different rainfall regimes? An example in southeast Queensland, Australia
}

\author{
LEILA ESLAMI-ANDARGOLI, ${ }^{1 \star}$ PAT DALE ${ }^{1,2}$ AND NEIL SIPE ${ }^{1,3}$ \\ ${ }^{1}$ Griffith School of Environment, Griffith University, Nathan Campus, Nathan, Qld 4111, Australia \\ (Email: l.eslamiendargoli@griffith.edu.au), ${ }^{2}$ Environmental Futures Centre, ••, ••, and ${ }^{3}$ Urban Research \\ Program, $\bullet, \cdot \bullet$
}

\begin{abstract}
The aim of this study was to investigate the interactions of natural and anthropogenic variables at different spatial scales related to changes in mangrove distribution during a relatively wet period (1972-1990) and a dry period (1991-2004) in subtropical eastern Australia. Previous research has demonstrated that mangroves are encroaching into salt marsh. Mangrove spatial change in southeast Queensland is related generally to landscape variables especially during the relatively wet period. What has not been explored is the spatial scale of the influence under the two rainfall regimes (wet and dry) and that is the aim of this paper. Ten sites were examined at different levels of resolution including catchment, sub-catchment and two buffer zones (1000 and $500 \mathrm{~m}$ ), under the period of relatively higher and lower rainfall. Land use was ascertained from Landsat satellite imagery using Maximum Likelihood Classification techniques. Partial least squares regression analysis was used to study the relationships between the predictor variables and the rate of change in the mangrove distribution. The research has found that the impact of land use/cover on the encroachment of mangrove into saltmarsh can vary and appears to be related to rainfall patterns, which in turn affect hydrological connectivity. A major finding of this research was that the changing spatial patterns of mangroves during the wet period was more a function of land use/cover pattern and population density at the sub-catchment level, whereas during drier periods it was more affected by the local effects of nearby land use/cover in buffer zones.
\end{abstract}

Key words: land use/cover, mangrove, population, rainfall, scale.

\section{INTRODUCTION}

Mangroves are important components of the intertidal zone in the tropics and sub-tropics. They are affected by the interaction of terrestrial, marine and climatic factors (D'iorio et al. 2007). These may include both natural and anthropogenic factors. Mangroves are sensitive indicators of alterations induced by anthropogenic and climatic forces (Alongi 2002; Smith \& Chow-Fraser 2010). Although changes to mangroves have occurred in the past in response to long-term environmental change, these are expected to become more rapid and widespread in coming decades in response to human land use and global climate changes (Lyford et al. 2003). The sensitivity of mangroves to environmental change is reflected in mangrove encroachment into salt marshes in eastern Australia over at least six decades which has been well-documented (e.g., Eslami-Andargoli et al. 2009; Saintilan et al. 2009).

*Corresponding author

Accepted for publication March 2012.

(C) 2012 The Authors

Journal compilation (C) 2012 Ecological Society of Australia
Mangrove incursion into saltmarshes is related to larger-scale global drivers such as climate change (sealevel rise, changes in precipitation) and smaller scale regional and local drivers (mostly associated with land use/cover change), as well as the interaction between them (Eslami-Andargoli et al. 2009, 2010; Saintilan et al. 2009; Morrisey et al. 2010). For local conservation management, it is important to identify the effect of spatial scale in order to mitigate the impacts of the drivers (Houlahan \& Findlay 2003).

Sea level change has been suggested as a driver of mangrove change. Although sea-level fluctuations have affected mangrove distribution over the long-term (Field 1995; Gilman 2004), in the short-term, regional rainfall and catchment runoff may be more significant than sea level changes (Snedaker 1995; EslamiAndargoli et al. 2009, 2010).

Wetlands are functionally interdependent with other parts of their landscape setting (Preston \& Bedford 1988). Evaluating the effects of climate variability and anthropogenic activities on inter-tidal coastal wetlands requires improved understanding of how the stressors themselves interact. Generally, there is no integrated model of mangrove expansion or decline that can 
apply to all mangrove ecosystems nor are the synergies between contributing factors well researched. In addition there is the issue of level of resolution or scale. To understand ecosystem patterns, the data and their analyses must match the scale of the processes responsible for those patterns (Levin 1992). For example, land use/cover has been reported to explain downstream conditions better in larger catchments than it does in smaller ones (Strayer et al. 2003; Opperman et al. 2005).

This paper therefore focuses on landscape characteristics related to mangrove spatial change at different spatial scales in a sub-tropical system and under two rainfall regimes (the latter already identified: Eslami-

2 Andargoli et al. 2009). The results of earlier research in the study area have indicated that, although rainfall was important for mangrove change, it also controlled the contribution of other factors such as land use and human population (Eslami-Andargoli et al. 2009, 2010). The earlier study showed that the period from 1972-1990 was significantly wetter than the 19902004 period (Eslami-Andargoli et al. 2009). There were significant differences in the rate of mangrove spatial change between the two periods. The later study investigated the relationship between the mangrove changes and landscape variables during a wet and a dry period, only at the sub-catchment level (Eslami-Andargoli et al. 2010). Although there was a significant relation between mangrove spatial changes and landscape variables during the wet period, there was no relationship during the dry period (EslamiAndargoli et al. 2010). This has raised the question of spatial scale of land use/cover influence and this paper extends and builds on the earlier research. The following are the research hypotheses:

1 There is a relationship between the spatial scale (e.g. catchment, sub-catchment, buffer zone) of landscape variables and mangrove change during periods of high and low rainfall; and

2 There is a relationship between the size of the surrounding area (catchment/sub-catchment) and the explanatory power of the statistical models.

\section{METHODS}

\section{Study area}

We selected 10 inter-tidal sites, based on their having substantial stands of mangroves and other wetland vegetation, and being classified as 'middle estuary' (Environmental Protection Agency 2007). They were located in six catchments and 10 sub-catchments that drain into northern Moreton Bay which is located in southeast Queensland, Australia $\left(27^{\circ} 20^{\prime} \mathrm{S}, 153^{\circ} 10^{\prime} \mathrm{E}\right)$ (Fig 1$)$. The climate is subtropical with rainfall and streamflow patterns associated with the different phases of the El Niño-Southern Oscillation (ENSO).

doi:10.1111/j.1442-9993.2012.02393.x
The catchments ranged in area from 80.8 to $707 \mathrm{~km}^{2}$ (Table 1) and the area of sub-catchments ranged between $3.9 \mathrm{~km}^{2}$ to $76 \mathrm{~km}^{2}$; we calculated the catchment and subcatchment area using the data provided by the Queensland Environmental Protection Agency (2007). The main land uses in these catchments are pine plantations, especially in the north, and built-up areas in the south near the state capital city, Brisbane.

\section{Mangrove spatial change}

We used ArcGIS software (ESRI Inc. version 9.3) and aerial photos for 1972, 1990 (the most significant year that change in rainfall pattern occurred; Eslami-Andargoli et al. 2009) and 2004. We scanned the aerial photos and imported them into ArcGIS 9.3. All the digital photos were registered to GDA94, MGA 56 map system with an RMS (root mean squarer) error of less than 0.5 pixels to on-screen digitizing the boundary of mangrove and salt marsh/saltpan. After being validated, we used these maps to calculate the area and rate of mangrove change (the percentage of net annual increase in area covered) during the period of high (1972-1990) and low (1990-2004) rainfall (Eslami-Andargoli et al. 2009).

\section{Land use/cover classification}

In the study area, we selected three important land cover/uses which, based on the literature, would be likely to impact inter-tidal wetland systems. These were agriculture, pine plantation forests and built-up areas (impervious surfaces). Grassland was excluded because the sub-categories such as grazed/ungrazed, improved/unimproved could not be distinguished on the imagery. To produce the land use/cover maps, we selected three predominantly cloud-free images from the Landsat satellite series: 1972,1990 and 2004 to provide periods consistent with the rainfall data. Image processing and accuracy assessment was described in Eslami-Andargoli et al. (2010).

The proportion of each land use/cover class was calculated at six spatial scales: all catchments $(n=6)$, large catchments $\left(>110 \mathrm{~km}^{2}, n=4\right)$, all sub-catchments $(n=10)$, large subcatchments $\left(>13 \mathrm{~km}^{2}, n=7\right)$, and 1000 and $500 \mathrm{~m}$ buffer areas from the wetland edge. The average value at the start and the end of each period (pre- and post-1990) was used for analysis and compared using a $t$-test. We extracted catchment and sub-catchment land use/cover using the southeast Queensland sub-catchment dataset (Environmental Protection Agency 2007). For the buffer zones, the buffer analysis function in ArcGIS 9.3 was used to extract land use/cover data for buffers at 1000 and $500 \mathrm{~m}$ from the wetland edge.

\section{Population density}

To include population density in our analysis, we obtained census data for 1972, 1990 and 2004 from the Australian Bureau of Statistics (ABS). Population densities were estimated for each catchment, sub-catchment and buffer zone based on a comparison of census boundaries and catchment 


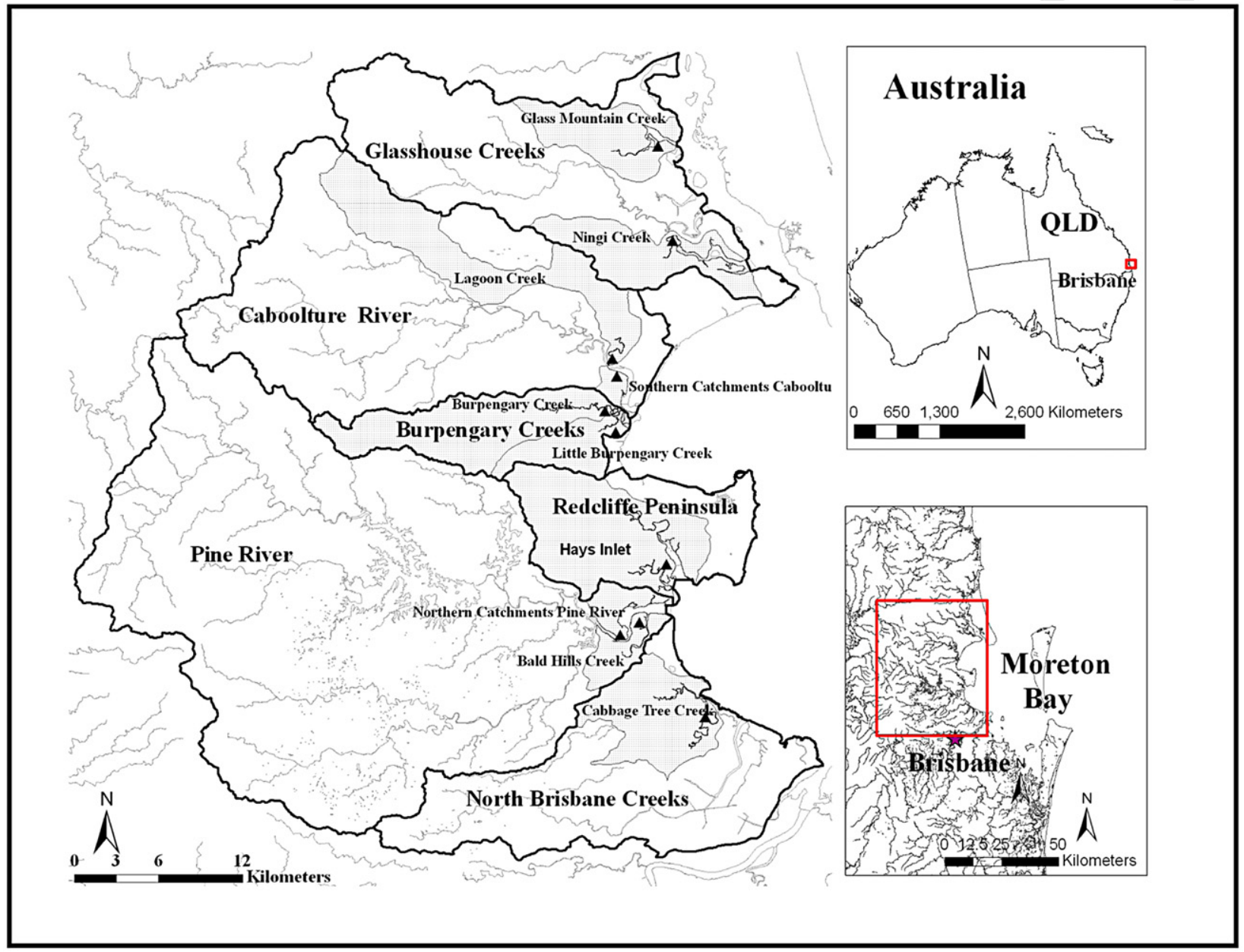

Fig. 1. Locality map of study sites, northern Moreton Bay, Queensland, Australia. The boundaries of catchments are shown with bold lines and the sub-catchments are indicated in grey.

Table 1. Area of the catchments and sub-catchments of study area (for location refer to Fig. 1)

\begin{tabular}{lcrr}
\hline Catchment & Area $\left(\mathrm{km}^{2}\right)$ & Sub-catchment & Area $\left(\mathrm{km}^{2}\right)$ \\
\hline North Brisbane Creeks & 212.0 & Cabbage Tree Creek & 45.3 \\
Pine River & 707.1 & Bald Hills Creek & 13.0 \\
& & Pine River, northern catchment & 9.6 \\
Redcliffe Peninsula & 108.4 & Hays Inlet & 76.1 \\
Burpengary Creek & 80.8 & Little Burpengary Creek & 19.9 \\
& & Burpengary Creek & 60.4 \\
Caboolture River & 361.7 & Caboolture River, southern catchment & 3.9 \\
& & Lagoon Creek & 65.8 \\
Glasshouse Creeks & 246.3 & Ningi Creek & 39.4 \\
& & Glass Mountain Creek & 34.3 \\
\hline
\end{tabular}

boundaries using aerial photography as in Eslami-Andargoli et al. (2010). We compared the average value of each period, using the $t$-test.

\section{Data analysis}

We used partial least squares regression (PLSR) to analyse and identify the relation between the rate of mangrove

(C) 2012 The Authors

Journal compilation (C) 2012 Ecological Society of Australia change and land use and population density at each spatial scale during the wet (pre-1990) and the dry (post-1990) periods. The PLSR is an alternative to the ordinary least square (OLS) regression. It is designed to cope with problems such as small datasets, high dimensionality and multicollinearity. These characteristics make the method useful in ecological studies, as ecological phenomena are usually described by a large array of variables, which are generally not independent. Moreover, in some ecological 
research sample size cannot be enlarged by increasing sampling effort. Therefore, these data may have many predictors compared with the number of observations (Carrascal et al. 2009). In such a situation, PLSR is a powerful method for finding a few underlying predictive factors that account for most of the variation in the response variable. It uses a principal components analysis and multiple regression approach to generalize and combine features (Abdi 2003). It establishes the relationship between two matrices ( $\mathrm{X}$ and $\mathrm{Y}$ ) and this identifies the optimal number of extracted factors or latent variables, that is, those not directly observed but which are derived from direct observations.

We log-transformed the data to normalize the values. The values were then centred and scaled to a mean of zero and variance of one. To determine the optimal number of latent variables for the PLSR we compared the RMS errors of cross-validation of predictions, using various numbers of extracted factors. The selected number of factors was the minimum that had residuals not significantly larger than the model that had the minimum predicted residual sum of squares (Van der Voet 1994). We applied the optimal model and checked for outliers. Then the correlation was calculated for each $\mathrm{X}$ (land use/cover type and population density) with the $\mathrm{Y}$ (rate of mangrove change) and level of significance ( $P$-value). As part of the PLSR analysis the variable importance projection (VIP) values assess the effect of each predictor variable in explaining variation in the response variable and so the values for the predictor variables were noted. The VIP values and the regression coefficients are thus used to filter out the less important variables (small VIP and coefficient values), thereby retaining only the significant ones. The regression coefficients represent the importance each factor has in the prediction of the response and the VIP value represents the value of each predictor in fitting the PLSR model for both predictors and responses. Finally, models for each time period and each spatial scale were compared to find the one with the greatest explanatory power. PLSR was performed in SAS (version 9.1).

\section{RESULTS}

The results are presented in two parts. First, the changes in land use/cover and population are provided at catchment, sub-catchment and buffer zone scales; second, the PLSR analysis results are used to demonstrate the relationships between mangrove spatial change and the landscape variables (land use/cover type and population).

\section{Land use/cover classification}

The following sections describe the estimated proportions of the three land use/covers at each spatial scale for the period pre- and post-1990. As an example, Figure 2 shows the 2004 land use/cover map in the catchments of North Brisbane Creek and Glass
Mountain Creek. The boundary of the sub-catchment and buffer zones are also shown.

\section{Catchment}

At the most general catchment level, built-up areas covered the major southern part of study area near Brisbane (41.9-53.2\% of the catchment area), whereas plantation forest, and agriculture were more common in the northern area as shown in Table 2. Built-up areas experienced a significant increase in the overall means from $13.2 \%$ to $21.4 \%$ between the preand post-1990 periods $(t=-3.85$, d.f. $=5, P=0.012)$. In contrast both the reduction in the means of the total proportion of plantation forest (means of $11.6 \%$ and $10.3 \%, t=1.32$, d.f. $=5, P=0.24)$ and the slight increase in agriculture area (means of $3.1 \%$ and $3.3 \%$, $t=-3.32$, d.f. $=5, P=0.76)$ were not statistically significant.

\section{Sub-catchment}

At the local sub-catchment level, the dominant land use class remained similar to that in the catchment in both periods (Eslami-Andargoli et al. 2010). Briefly, built-up areas increased significantly between periods with overall means from $10.0 \%$ to $20.4 \%(t=-5.25$, d.f. $=9, P<0.001)$. There was a slight non-significant decrease in the area of plantation forests (means of $15.1 \%$ and $13.4 \%, t=1.11$, d.f. $=9, P=0.29$ ), while the coverage of agriculture remained relatively stable (means of $3.2 \%$ and $3.4 \% t=-0.44$, d.f. $=9$, $P=0.66)$.

\section{Buffer zones}

In the vicinity of the wetlands, the land use/cover in $1000 \mathrm{~m}$ and $500 \mathrm{~m}$ buffer areas showed the same general pattern as at the catchment and sub-catchment level. Built-up areas were the dominant land use/cover in southern sites such as Cabbage Tree Creek and Bald Hills Creek and plantation forest was the dominant land use/cover of Glass Mountain Creek, which is located further north. The overall means of the total percentage of built-up areas in the pre-1990 and post1990 increased at both distances. In the $1000 \mathrm{~m}$ buffer zone, the means were $7.9 \%$ and $16.5 \%(t=-5.31$, d.f. $=9, P<0.001)$, and in the $500 \mathrm{~m}$ buffer zone means were $5.78 \%$ and $14.79 \%(t=-2.15$, d.f. $=9$, $P=0.059)$. Neither the reductions in plantation forest nor the increases in agriculture area were statistically significant. 

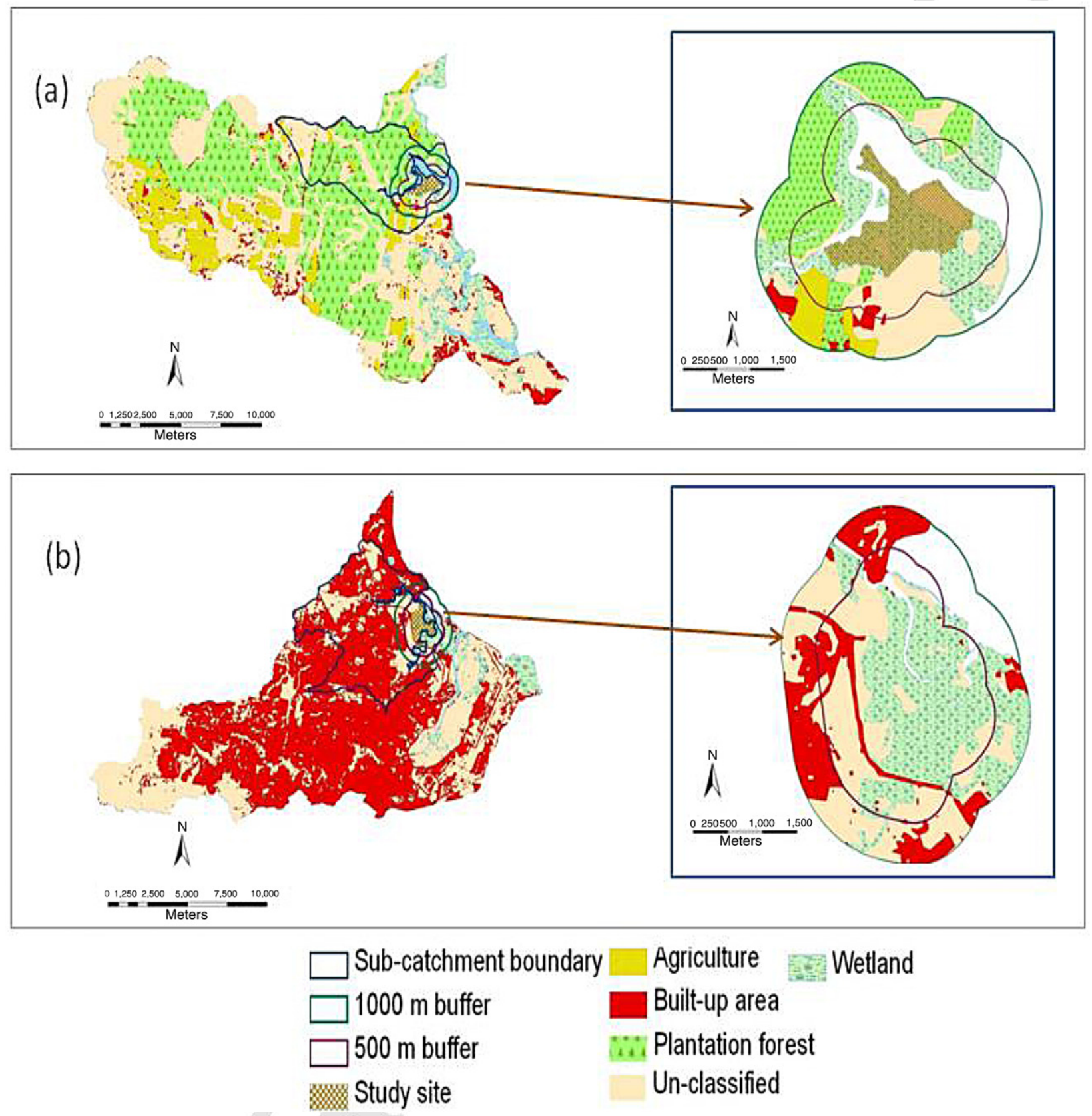

Fig. 2. Land use/cover maps of catchments and buffer zones of (a) Glass Mountain Creek and (b) North Brisbane Creek in 2004. The boundary of the sub-catchment and buffer zones are also illustrated in the catchments map.

\section{Population density}

The average population density at each period in the catchment, sub-catchment and buffer zones is provided below.

\section{Catchment}

All catchments experienced an increase in population density (Table 2). The increase in the overall mean (C) 2012 The Authors

Journal compilation (C) 2012 Ecological Society of Australia population density from 268.7 persons per $\mathrm{km}^{2}(\mathrm{SD}=$ $349.99)$ in the first period to $377.7(\mathrm{SD}=424.89)$ in the second period, was statistically significant $(t=$ -3.53, d.f. $=5, P=0.017$ ). North Brisbane Creek, with 982.7 persons per $\mathrm{km}^{2}$ in the first period and 1087.1 persons per $\mathrm{km}^{2}$ in the second period, was the most densely populated study area catchment. In contrast, the more northern Glasshouse Creek's catchment, with 10.8 persons per $\mathrm{km}^{2}$ in the first period and 28.5 persons per $\mathrm{km}^{2}$ in the second period, had the doi:10.1111/j.1442-9993.2012.02393.x 
Table 2. Average percentage of agriculture (\%Ag), built-up (\%Built) and plantation forest (\%P forest) and population density (Pop D) at the different catchments pre- and post-1990

\begin{tabular}{|c|c|c|c|c|c|c|c|c|}
\hline \multirow[b]{2}{*}{ Catchment } & \multicolumn{4}{|c|}{ Pre-1990 } & \multicolumn{4}{|c|}{ Post-1990 } \\
\hline & $\% \mathrm{Ag}$ & $\%$ Built & $\% \mathrm{P}$ forest & Pop D & $\% \mathrm{Ag}$ & $\%$ Built & $\% \mathrm{P}$ forest & Pop D \\
\hline North Brisbane Creeks & 0.6 & 41.9 & 0 & 982.7 & 0.1 & 53.2 & 0 & 1087.1 \\
\hline Pine River & 1.5 & 3.4 & 0.6 & 58.7 & 1.3 & 7.5 & 0.5 & 122 \\
\hline Redcliffe Peninsula & 3.3 & 21.2 & 11.5 & 491.5 & 2.8 & 35.6 & 6.4 & 708 \\
\hline Burpengary Creek & 2.7 & 7.6 & 9.4 & 44.5 & 1.3 & 20.3 & 9.1 & 225.5 \\
\hline Caboolture River & 4.7 & 3.1 & 11 & 24.2 & 5.3 & 8.1 & 8.4 & 95 \\
\hline Glasshouse Creeks & 5.6 & 1.9 & 36.8 & 10.8 & 8.7 & 3.7 & 37.7 & 28.5 \\
\hline Mean & 3.1 & 13.2 & 11.6 & 268.7 & 3.3 & 21.4 & 10.3 & 377.7 \\
\hline
\end{tabular}

Table 3. Summary of the results of the partial least squares regression (PLSR) models at each spatial scale

\begin{tabular}{|c|c|c|c|c|}
\hline \multirow[b]{2}{*}{ Scale of study } & \multicolumn{2}{|c|}{ Pre-1990 } & \multicolumn{2}{|c|}{ Post-1990 } \\
\hline & $R^{2}$ & $P$-value & $R^{2}$ & $P$-value \\
\hline All catchments & & & & \\
\hline Large catchments & & & & \\
\hline All sub-catchments & 0.61 & 0.008 & 0.18 & NS \\
\hline Large sub-catchments & 0.68 & 0.023 & 0.25 & NS \\
\hline Buffer area $(1000 \mathrm{~m})$ & 0.54 & 0.015 & 0.38 & NS \\
\hline Buffer area $(500 \mathrm{~m})$ & 0.58 & 0.011 & 0.70 & 0.003 \\
\hline
\end{tabular}

'No significant component was provided by the PLSR analysis.

lowest population density among the study area catchments.

\section{Sub-catchment}

At the sub-catchment level, there was also a significant increase of nearly $79 \%$ in the overall mean population density from 180.6 persons per $\mathrm{km}^{2}(\mathrm{SD}=294.37)$ pre-1990 to $323.9(\mathrm{SD}=360.54)$ post-1990 $(t=$ -4.46, d.f. $=9, P=0.001)$ (Eslami-Andargoli et al. 2010).

\section{Buffer zones}

Population density increased in most of the wetlands buffer zones. The increase in population density within $1000 \mathrm{~m}$ was statistically significant (means of 109.6 and 157.1, $t=-2.74$, d.f. $=9, P=0.022$ ). However, within $500 \mathrm{~m}$ distance, the increase from 73.5 to 84.4 persons per $\mathrm{km}^{2}$ was not significant $(t=-2.03$, d.f. $=9, P=0.073$ ). In both periods, the highest population density in the $1000 \mathrm{~m}$ and $500 \mathrm{~m}$ buffers was at Bald Hills Creek and the comparable lowest densities were at Glass Mountain Creek.

doi:10.1111/j.1442-9993.2012.02393.x

\section{PLSR analysis}

The results of the PLSR models exploring the relationships between the rate of mangrove change and landscape variables at each spatial scale are summarized in Table 3 and discussed below. At the 'all catchment' and 'large catchment' level, the PLSR analysis did not provide any significant component either before or after 1990 to explain the original variance in response. Thus, no relationship between mangrove change with land use/cover and population density was established. No further results at this level are presented here. Similarly, there were no significant results in the dry period at the 'all subcatchments', 'large sub-catchments' and the ' $1000 \mathrm{~m}$ buffer zone'.

\section{Sub-catchment}

The results of the PLSR models for all sub-catchment and for large sub-catchment are shown in Table $4 \mathrm{a}$. The PLSR analysis for all sub-catchments $(n=10)$ during the pre-1990 wet period provided one component (comp), accounting for $60.7 \%$ of the original variance in the response considering $27 \%$ of the infor- 
Table 4. The partial least squares regression (PLSR) results of the component of all models at (a) sub-catchment level and (b) buffer zone

\begin{tabular}{|c|c|c|c|c|}
\hline \multirow[b]{3}{*}{ (a) Variable } & \multicolumn{2}{|c|}{ All sub-catchments $(n=10)$} & \multicolumn{2}{|c|}{ Large sub-catchments $(n=7)$} \\
\hline & $\begin{array}{l}\text { Rate of change } \\
\text { pre-1990 }\end{array}$ & $\begin{array}{l}\text { Rate of change } \\
\text { post-1990 }\end{array}$ & $\begin{array}{l}\text { Rate of change } \\
\text { pre-1990 }\end{array}$ & $\begin{array}{l}\text { Rate of change } \\
\text { post- } 1990\end{array}$ \\
\hline & $\mathrm{W}$ comp ${ }^{\dagger}$ & W comp & W comp & W comp \\
\hline Population density & 0.262 & -0.295 & -0.021 & -0.437 \\
\hline Agriculture (\%) & -0.851 & -0.049 & -0.854 & 0.027 \\
\hline Built-up (\%) & 0.005 & -0.618 & -0.262 & -0.629 \\
\hline Plantation forest (\%) & 0.514 & 0.848 & 0.541 & 0.731 \\
\hline$R^{2}$ & 0.607 & 0.184 & 0.675 & 0.247 \\
\hline \multirow[t]{3}{*}{$P$-value } & 0.008 & 0.216 & 0.023 & 0.256 \\
\hline & \multicolumn{2}{|c|}{$500 \mathrm{~m}$ buffer zone } & \multicolumn{2}{|c|}{$1000 \mathrm{~m}$ buffer zone } \\
\hline & $\begin{array}{l}\text { Rate of change } \\
\text { pre-1990 }\end{array}$ & $\begin{array}{l}\text { Rate of change } \\
\text { post- } 1990\end{array}$ & $\begin{array}{l}\text { Rate of change } \\
\text { pre-1990 }\end{array}$ & $\begin{array}{l}\text { Rate of change } \\
\text { post- } 1990\end{array}$ \\
\hline (b) Variable & W comp & W comp & W comp & W comp \\
\hline Population density & 0.444 & 0.215 & 0.480 & 0.019 \\
\hline Agriculture (\%) & 0.066 & -0.702 & -0.171 & -0.501 \\
\hline Built-up (\%) & 0.015 & -0.395 & 0.369 & -0.275 \\
\hline Plantation forest (\%) & 0.914 & 0.633 & 0.799 & 1.121 \\
\hline$R^{2}$ & 0.578 & 0.699 & 0.543 & 0.380 \\
\hline$P$-value & 0.011 & 0.003 & 0.015 & 0.058 \\
\hline
\end{tabular}

tWeights of each variable in the PLSR component. PLSR weights whose squares are larger than 0.2 are shown in bold type, as they contain a relatively large information content for each component. Note the significance $(P)$ value for each component.

mation in the predictor variables $(P=0.008)$. The information content of this component was mostly (93\%) associated with the per cent coverage of agriculture and of plantation forest.

The VIP values for each environmental variable were plotted for all models (Fig 3a). They indicate that the per cent coverage of plantation forest was consistently the most relevant variable for explaining variation in mangrove change for both large sub-catchments and all sub-catchments (including the large ones). The percentage of agricultural area had a higher contribution to explaining the variation in mangrove change in the first (wet) period. However, its importance declined significantly during the dry period.

As noted above, the models explaining mangrove change at sub-catchment level (for all sub-catchments or large sub-catchments) were only significant during the first (wet) period. The models of the second (dry) period failed to explain the variation in the responses and were not further explored. Based on the regression coefficients and VIP values, the following variables were omitted from the pre-1990 models: the per cent coverage of built-up area from the model of all subcatchments and population density from the model of the large sub-catchments. Table 5a shows the results of

(C) 2012 The Authors

Journal compilation (C) 2012 Ecological Society of Australia the repeated PLSR analysis of the reduced data set. It indicates that mangrove change in both data sets was positively affected by the percentage of plantation forest and negatively by the percentage of agricultural area.

\section{Buffer zones}

The rates of mangrove change in both periods had a stronger relationship with the land use/cover and population density within the $500 \mathrm{~m}$ buffer than within the $1000 \mathrm{~m}$ buffer (Table 4b). The latter was not significant during the dry period.

Within the $500 \mathrm{~m}$ zone, the PLSR analysis for the pre-1990 (wet) period provided one component (comp), accounting for $58 \%$ of the original variance in the response considering $20.7 \%$ of the information in the predictor variables $(P=0.011)$. This component was mainly $(80 \%)$ associated with the per cent coverage of plantation forest. During the post-1990 (dry) period, the PLSR analysis provided a significant component accounting for $70 \%(P=0.003)$ of the original variance in the response considering $21.7 \%$ of the information in the predictor variables, which was 
(a)

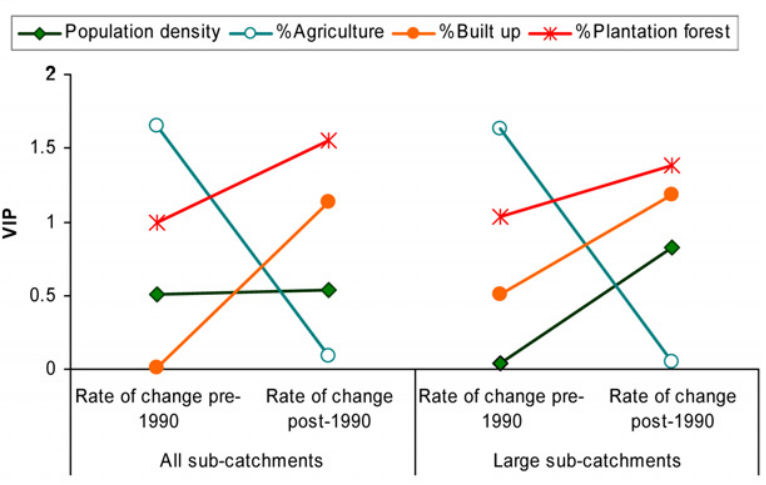

(b)

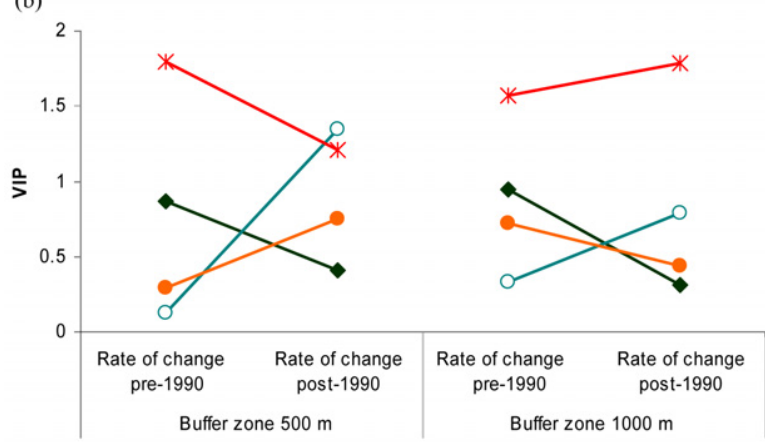

Fig. 3. Variable importance projection (VIP) values from partial least squares regression are plotted for (a) the models of all and large sub-catchment, and (b) the models of $500 \mathrm{~m}$ and $1000 \mathrm{~m}$ buffer zone, values greater than one are considered of high importance.

mostly $(81 \%)$ related to the per cent coverage of both agriculture and plantation forest.

The per cent coverage of plantation forest was consistently the most relevant variable for explaining the variation in mangrove change at this level of study as reflected by their VIP values (Fig $3 b$ ).

After removing less important variables and repeating the PLSR analysis, all the landscape variables in both the $1000 \mathrm{~m}$ and $500 \mathrm{~m}$ zones had a positive relationship with the rate of mangrove change during the pre-1990 (wet) period, except for agriculture (Table 5b). However, in the $500 \mathrm{~m}$ zone and during the dry period mangrove change was negatively related to the per cent coverage of agriculture and built-up area and positively to the per cent coverage of plantation forest (Table $5 b$ ).

\section{DISCUSSION}

This study identified connections between land use/ cover and population density and spatial change in mangrove extent that spanned a 32-year time period.
Based on the literature there may be factors extrinsic to the study focus that would contribute to explaining the results. The positive contribution of plantation forest to the models may be related to a number of major disturbances that occur during the rotation cycle of Pinus plantations including site preparation, fertilizer application, clear-fell harvesting and prescribed burning. All of these disturbances could affect the hydrological balance, leading to increased stream flows and runoff with increased organic and dissolved nutrient concentrations as well as a considerable rise in the unconfined watertable (Campbell \& Doeg 1989; Bubb \& Croton 2002; Ahern et al. 2006; Forsyth et al. 2006). As well, and as a consequence of increased stream flows, higher rates of sediment transport and deposition in receiving waters may, in turn, be a major driver of changes in mangrove distribution. The negative impact of the proportion of agricultural area on mangrove spatial change could be related to the input of agricultural chemicals that can adversely affect mangroves (Bell \& Duke 2005; Duke et al. 2005; Lewis et al. 2009). However, considering the low proportion of agricultural area in the sub-catchments and buffer zones, more research is needed to investigate this relationship. The amount of built-up area can also alter nutrient, sedimentation and hydrological regime. For example, increasing the area of impervious surface decreases ground water recharge and base flow (Arnold \& Gibbons 1996; Paul \& Meyer 2001; Tang et al. 2005; White \& Greer 2006) and this will intensify the effect of drought on the mangrove ecosystem. The interaction between higher nutrient availability and drought could increase the vulnerability of mangroves to environmental stresses and cause greater mortality of mangroves (Lovelock et al. 2009).

The nature of the effects of the landscape variables has been discussed in more detail in EslamiAndargoli et al. (2010), so this discussion focuses on the issues of scale and size. The current study identified the spatial scales at which landscape variables affected mangrove spatial changes over a 32-year time period during relatively wet and dry periods. Identifying the spatial scale at which land use influences wetland change may provide some insight into potential mechanisms driving the response (DeLuca et al. 2004).

\section{Scale}

The PLSR analysis enabled the assessment of the relative contribution of multiple factors to mangrove spatial change. The difference of the explanatory power of the PLSR model explaining mangrove

(C) 2012 The Authors

Journal compilation (C) 2012 Ecological Society of Australia 
Table 5. Final, significant partial least squares regression (PLSR) models of mangrove change at (a) sub-catchment level and (b) buffer zones

\begin{tabular}{|c|c|c|c|c|c|c|c|}
\hline \multirow[b]{2}{*}{ (a) Response variable } & & \multicolumn{6}{|c|}{ Predictor variables } \\
\hline & & Pop D & $\% \mathrm{Ag}$ & $\%$ Built & $\% \mathrm{P}$ forest & $R^{2}$ & $P$-value \\
\hline \multirow{3}{*}{$\begin{array}{l}\text { Mangrove rate of change (wetter } \\
\text { period pre-1990) }\end{array}$} & All sub-catchments & 0.20 & -0.65 & - & 0.39 & 0.61 & 0.008 \\
\hline & Large sub-catchments & - & -0.65 & -0.20 & 0.41 & 0.68 & 0.023 \\
\hline & & \multicolumn{6}{|c|}{ Predictor variables } \\
\hline (b) Response variable & & Pop D & $\% \mathrm{Ag}$ & $\%$ Built & $\% \mathrm{P}$ forest & $R^{2}$ & $P$-value \\
\hline \multirow{2}{*}{$\begin{array}{l}\text { Mangrove rate of change (Wetter } \\
\text { period pre-1990) }\end{array}$} & Buffer area $(1000 \mathrm{~m})$ & 0.39 & -0.14 & 0.30 & 0.64 & 0.54 & 0.015 \\
\hline & Buffer area $(500 \mathrm{~m})$ & 0.36 & - & 0.01 & 0.75 & 0.57 & 0.012 \\
\hline $\begin{array}{l}\text { Mangrove rate of change (Drier } \\
\text { period post-1990) }\end{array}$ & Buffer area $(500 \mathrm{~m})$ & 0.19 & -0.63 & -0.35 & 0.57 & 0.70 & 0.003 \\
\hline
\end{tabular}

$\% \mathrm{Ag}, \%$ Built, $\% \mathrm{P}$ forest: percentage of agriculture, built-up and plantation forest, respectively; Pop D, population density.

change during the pre-1990 (wet) period and post-1990 (dry) period indicated that rainfall indeed influenced the type and extent of the contribution of land use/cover and population density to the change in mangrove extent. Thus during the wet period more nutrient and pollutants would be carried downstream to the wetland than in the dry period. This suggestion is consistent with the changes in water quality reported by Chen et al. (2002) who found that surface runoff and underground flow during a rainy period had a strong effect on nonpoint-source pollutant loss and transport. Correll et al. (1992) also concluded that nutrient discharges from catchments that varied greatly among years were mostly due to inter-annual differences in rainfall. As well, the results of our study indicate that there is also a scale-dependent effect of development on mangrove spatial change during wet and dry periods.

At the catchment level in the study area, there was no effect of land use/cover and population density on mangrove change during the pre- or post-1990 period. However, at the sub-catchment level, landscape variables had strong relationships with mangrove change, but only during the period of higher rainfall. In contrast, during the dry period (post1990), only landscape variables within $500 \mathrm{~m}$ from the wetland edge had any significant effect. Higher precipitation during the wet period may increase direct linkages between upland land use and stream conditions, therefore, in the wet period the stream condition may better reflect cumulative effects of sub-catchment land use (Pan et al. 2004), and it may mask the impact of local variables (in buffer

(C) 2012 The Authors

Journal compilation (C) 2012 Ecological Society of Australia zones). In contrast, during the dry period, the impacts of nearby land use (specifically within $500 \mathrm{~m}$ from the wetland edge) were stronger and more significant, affecting mangroves probably already stressed by drought. Generally, it has been noted that land use/cover in the areas surrounding wetlands can greatly transform the hydrological cycle through affecting storage patterns and water discharge (Ruiz-Luna \& Berlanga-Robles 1999). Therefore, the impact of adjacent land use may be exaggerated during the drought when there is less fresh water input from rainfall or upland area.

\section{Size}

The explanatory power of the PLSR model increased only for the large sub-catchments. The greater predictive power in larger sub-catchments is consistent with the results of Strayer et al. (2003), Opperman et al. (2005) and Byrd et al. (2007), who studied the impact of catchment land use on downstream conditions. Strayer et al. (2003) suggested that the existence of stronger relationships between stream conditions and catchment land use/cover in large catchments compared with smaller one is because in smaller catchments the spatial arrangement of landscape patches or the management of such patches may have stronger effects on stream ecosystems than overall land use/cover. In another study, Benda and Dunne (1997) indicated that the difference in explanatory power between the catchment size classes is probably because larger catchments inte- 
grate random pulses of sediment occurring over their smaller sub-catchments and hence generate a more general effect. Thus, there is a tendency of smaller catchments to have more highly variable sediment that in a small catchment, a small land use disturbance could produce a relatively greater sediment signal than one occurring in a large catchment, where the overall land cover is more important (Opperman et al. 2005). This effect of spatial arrangement may be applied to buffer zones and is a topic for further research.

In conclusion, this study has shown that the interactions of natural and anthropogenic variables at different spatial scales are related to changes in mangrove distribution. The PLSR analysis has identified a scale-dependent effect of development on mangrove patterns during wet and dry periods. The research has found that the impact of land use/ cover on the encroachment of mangrove into saltmarsh can vary and appears to be related to rainfall patterns, which in turn affect the hydrological connectivity. Therefore, the changing spatial patterns of mangroves during a wet period are more a function of sub-catchment land use/cover pattern and population density, while during dry periods they may be more affected by local effects of nearby land use/ cover.

\section{ACKNOWLEDGEMENTS}

We thank the Queensland Department of Environment and Resource Management (DERM) (formerly the Environment Protection Agency) and the US GeoWe are also grateful to J. Chaseling for assistance with the statistical analysis. This work was supported by Griffith University.

\section{REFERENCES}

Abdi H. (2003) Partial least squares (PLS) regression. In: Encyclopedia of Social Sciences Research Methods (eds M. LewisBeck, A. Bryman \& T. Futing) pp. ••-••. Sage, Thousand Oaks.

Ahern K. S., Udy J. W. \& Pointon S. M. (2006) Investigating the potential for groundwater from different vegetation, soil and landuses to stimulate blooms of the cyanobacterium, Lyngbya majuscula, in coastal waters. Mar. Freshwater Res. 57, 177-86.

Alongi D. M. (2002) Present state and future of the world's mangrove forests. Environ. Conserv. 29, 331-49.

Arnold C. \& Gibbons C. (1996) Impervious surface coverage: the emergence of a key environmental indicator. F. Am. Plann. Assoc. 62, 243-58. fluxes than large catchments. Furthermore, it is likely logical Survey (USGS) for providing the primary data.

Bell A. M. \& Duke N. C. (2005) Effects of Photosystem II inhibiting herbicides on mangroves - preliminary toxicology trials. Mar. Pollut. Bull. 51, 297-307.

Benda L. \& Dunne T. (1997) Stochastic forcing of sediment supply to channel networks from landsliding and debris flow. Water Resour. Res. 33, 2849-63.

Bubb K. \& Croton J. (2002) Effects on catchment water balance from the management of Pinus plantations on the coastal lowlands of south-east Queensland, Australia. Hydrol. Process. 16, 105-17.

Byrd K., Kelly N. \& Merenlender A. (2007) Temporal and spatial relationships between watershed land use and salt marsh disturbance in a Pacific estuary. Environ. Manag. 39, 98-112.

Campbell I. \& Doeg T. (1989) Impact of timber harvesting and production on streams: a review. Aust. F. Mar. Freshwater Res. 40, 519-39.

Carrascal L. M., Galván I. \& Gordo O. (2009) Partial least squares regression as an alternative to current regression methods used in ecology. Oikos 118, 681-90.

Chen L., Fu B., Zhang S., Qiu J., Guo X. \& Yang F. (2002) A comparative study on nitrogen-concentration dynamics in surface water in a heterogeneous landscape. Environ. Geol. 42, 424-32.

Correll D. L., Jordan T. E. \& Weller D. E. (1992) Nutrient flux in a landscape: effects of coastal land use and terrestrial community mosaic on nutrient transport to coastal waters. Estuar. Coast. 15, 431-42.

D'iorio M., Jupiter S. D., Cochran S. A. \& Potts D. C. (2007) Optimizing remote sensing and GIS tools for mapping and managing the distribution of an invasive mangrove (Rhizophora mangle) on South Molokai, Hawaii. Mar. Geod. 30, 125-44.

DeLuca W., Studds C., Rockwood L. \& Marra P. (2004) Influence of land use on the integrity of marsh bird communities of Chesapeake Bay, USA. Wetlands 24, 837-47.

Duke N. C., Bell A. M., Pederson D. K., Roelfsema C. M. \& Nash S. B. (2005) Herbicides implicated as the cause of severe mangrove dieback in the Mackay region, NE Australia: consequences for marine plant habitats of the GBR World Heritage Area. Mar. Pollut. Bull. 51, 308-24.

Environmental Protection Agency (2007) South East Queensland Watertypes Dataset Version 1.1. Manager, Resource Assessment Unit, Planning Services Branch, Planning Division, Environmental Protection Agency, Queensland.

Eslami-Andargoli L., Dale P., Sipe N. \& Chaseling J. (2009) Mangrove expansion and rainfall patterns in Moreton Bay, Southeast Queensland, Australia. Estuar. Coast. Shelf Sci. 85, 292-8.

Eslami-Andargoli L., Dale P., Sipe N. \& Chaseling J. (2010) Local and landscape effects on spatial patterns of mangrove forest during wetter and drier periods: Moreton Bay, Southeast Queensland, Australia. Estuar. Coast. Shelf Sci. 89, 53-61.

Field C. D. (1995) Impact of expected climate-change on mangroves. Hydrobiologia 295, 75-81.

Forsyth A., Bubb K. \& Cox M. (2006) Sediment and nutrient losses from exotic Pinus plantation management operations under simulated rainfall. Aust. For. 69, 58-67.

Gilman E. (2004) Assessing and Managing Coastal Ecosystem Response to Projected Relative Sea-Level Rise and Climate Change. Prepared for the International Research Foundation for Development Forum on Small Island Developing 
States: Challenges, Prospects and International Cooperation for Sustainable Development. Contribution to the Barbados + 10 United Nations International Meeting on Sustainable Development of Small Island Developing State, Port Louis, Mauritius.

Houlahan J. \& Findlay C. (2003) The effects of adjacent land use on wetland amphibian species richness and community composition. Can. F. Fish. Aquat. Sci. 60, 107894.

Levin S. (1992) Promoting the Science of Ecology. Ecology 73, 1943-67.

Lewis S. E., Brodie J. E., Bainbridge Z. T. et al. (2009) Herbicides: a new threat to the Great Barrier Reef. Environ. Pollut. 157, 2470-84.

Lovelock C. E., Ball M. C., Martin K. C. \& Feller I. C. (2009) Nutrient enrichment increases mortality of mangroves. PLOS ONE 4, e5600.

Lyford M., Jackson S., Betancourt J. \& Gray S. (2003) Influence of landscape structure and climate variability on a late Holocene plant migration. Ecol. Monogr. 73, $567-83$.

Morrisey D. J., Swales A., Dittmann S., Morrison M. A., Lovelock C. E. \& Beard C. M. (2010) The ecology and management of temperate mangroves. Oceanogr. Mar. Biol. Annu. Rev. 48, 43-160.

Opperman J., Lohse K., Brooks C., Kelly N. \& Merenlender A. (2005) Influence of land use on fine sediment in salmonid spawning gravels within the Russian River Basin, California. Can. F. Fish. Aquat. Sci. 62, 2740-51.

Pan Y., Herlihy A., Kaufmann P., Wigington J., Van Sickle J. \& Moser T. (2004) Linkages among land-use, water quality, physical habitat conditions and lotic diatom assemblages: a multi-spatial scale assessment. Hydrobiologia 515, 59-73.
Paul M. J. \& Meyer J. L. (2001) Streams in the urban landscape. Anпu. Rev. Ecol. Syst. 32, 333-65.

Preston E. M. \& Bedford B. L. (1988) Evaluating cumulative effects on wetland functions: a conceptual overview and generic framework. Environ. Manag. 12, 565-83.

Ruiz-Luna A. \& Berlanga-Robles C. (1999) Modifications in coverage patterns and land use around the HuizacheCaimanero lagoon system, Sinaloa, Mexico: a multitemporal analysis using LANDSAT images. Estuar. Coast. Shelf Sci. 49, 37-44.

Saintilan N., Rogers K. \& Howe A. (2009) Geomorphology and habitat dynamics. In: Australian Saltmarsh Ecology (ed. N. Saintilan) pp. 53-75. CSIRO Publishing, Collinwood.

Smith L. A. \& Chow-Fraser P. (2010) Impacts of adjacent land use and isolation on marsh bird communities. Environ Manag. 45, 1040-51.

Snedaker S. C. (1995) Mangroves and climate-change in the Florida and Caribbean region - scenarios and hypotheses. Hydrobiologia 295, 43-9.

Strayer D., Beighley R., Thompson L. et al. (2003) Effects of land cover on stream ecosystems: roles of empirical models and scaling issues. Ecosystems 6, 407-23.

Tang Z., Engel B., Pijanowski B. \& Lim K. (2005) Forecasting land use change and its environmental impact at a watershed scale. F. Environ. Manag. 76, 35-45.

Van der Voet H. (1994) Comparing the predictive accuracy of models using a simple randomization test. Chemometr. Intell. Lab. 25, 313-23.

White M. \& Greer K. (2006) The effects of watershed urbanization on the stream hydrology and riparian vegetation of Los Penasquitos Creek, California. Landsc. Urban Plann. 74, 125-38. 